\title{
Clean Metal Spray Forming
}

\author{
W.T. Carter, Jr.†, M.G. Benz $\uparrow$, J.K. Browning $\dagger$, R.J. Zabala $\dagger$, B.A. Knudsen $\dagger$, \\ R.M. Forbes Jones*, R.M. Davis* \\ $\uparrow$ General Electric Corporate Research \& Development \\ * Allvac, A Division of Allegheny Teledyne Industries, Inc.
}

\begin{abstract}
Clean Metal Spray Forming (CMSF) is a new process in which the melt pool from an Electroslag Refining (ESR) furnace is used as the source for a liquid metal stream to be directly processed via spray forming. The process takes advantage of the refining function of the ESR process and the economy of the spray forming process to yield material that is oxide-free, finegrained, equiaxed, homogeneous, and thus acceptable for fatigue-life critical applications. The controlled transfer of liquid metal from the ESR pool to the spray forming system is performed using a ceramic-free cold-walled-induction guide, which is a segmented induction heated copper funnel. A pilot plant for development of the concept using nickel-based alloys has been constructed and is operational. Oxide cleanliness, microstructure, and mechanical properties of Alloy 718 processed through the system will be discussed.
\end{abstract}

\section{Introduction}

Ceramic inclusions play a significant role in the low-cycle-fatigue life of components made from superalloys [1,2]. Mechanistically, a ceramic inclusion is more brittle than surrounding metal and will crack early in life, possibly as early as the first loading cycle. The cracked inclusion acts as a crack starter for the surrounding metal and may lead to early fatigue failure. Since a large fraction of the fatigue life of any part occurs while cracks are short, it is important to eliminate or limit the size of the ceramic inclusions. This requirement poses a metals processing challenge that has been aggressively attacked in the cast \& wrought industry and in the powder metallurgy industry.

In the cast \& wrought industry, a high level of cleanliness is achieved using a triple melt procedure in which Vacuum Induction Melting (VIM) is used to achieve composition, Electroslag Refining (ESR) is used to achieve cleanliness [3], and Vacuum Arc Remelting (VAR) is used to achieve microstructure and homogeneity. In the powder metallurgy industry, cleanliness is achieved by sieving the powder, and through careful handling during subsequent canning, vacuum degassing, and extrusion. The primary oxide removing process in cast \& wrought processing is the ESR step and the primary oxide removing step in powder metallurgy is the sieve step.

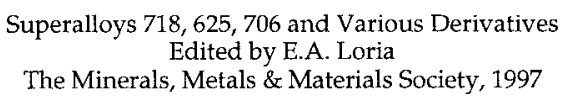




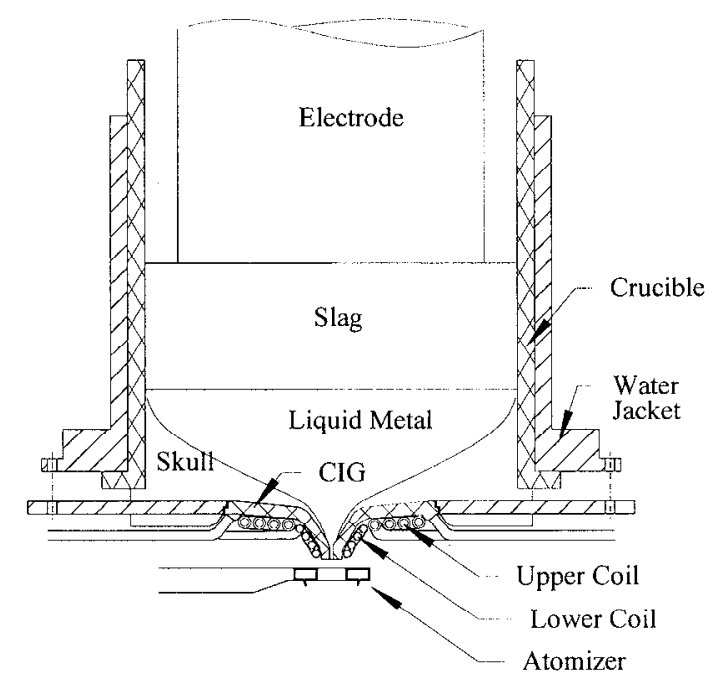

Figure 1 Clean metal spray forming concept.

\section{Spray Forming of ESR Liquid Metal}

Spray forming is the term applied to a process in which a stream of liquid metal is gas atomized to form a spray of fine liquid metal droplets, which are accelerated from the atomization zone by fast-flowing atomizing jets. The droplet trajectories are interrupted with a collector that collects and solidifies the droplets into a coherent, near-fully-dense preform. Continuous movement of the collector and atomizer along with careful control of the gas-tometal flow ratio allows large preforms to be produced. In this process, the liquid metal is cooled so that it loses most $(>75 \%)$ of its heat of fusion to the atomizing gas while in flight. The balance is lost to the preform and impinging gases after deposition. The spray forming process is capable of producing fine-grained homogeneous microstructures with equiaxed grains and $>98 \%$ theoretical density for a wide range of alloys $[4,5,6]$. The process has been studied extensively for several metals and in particular for nickel-base alloys by authors including Bricknell [7], Fiedler [8,9], Chang [10], Kennedy [11], Benz [12,13], Moran [14], Huron [15], and Prichard [16].

Spray forming may compete economically with existing cast \& wrought technologies if the resulting geometric shape is "near-net" resulting in substantially less material loss during subsequent processing than with conventional routes. Likewise, spray forming represents an economical alternative to powder processing for billet making because of the reduced number of processing steps and increased yield. In the past, this second possibility has not been exploited as a cost-effective alternative for superalloys to be used in critical fatigue-limited applications because of the lack of a primary oxide removing process. It is a solution to this problem that is discussed here.

The oxide removal approach taken for this work is shown in Figure 1 in which spray forming is performed directly from the refined ESR melt pool. A consumable electrode, cast from VIM, is fed into a pool of hot liquid slag (e.g., calcium fluoride, calcium oxide, and alumina) wherc it melts. As in conventional ESR, the electrode melts and any oxide impurities are exposed to the hot liquid slag where they dissolve. The slag is kept hot by passing an clectric current from the electrode, through the slag, and into the liquid metal pool. Liquid metal falls through the slag to form a pool of refined liquid metal bencath the slag. A bottom-pouring system referred to as the Cold-Walled-Induction Guide, or CIG is used to transfer the liquid metal to the spray forming chamber as a steady stream, which is subsequently gas atomized to form a spray of 
rapidly cooling metal droplets. The droplets are collected on a growing preform as a dense equiaxed structure of fine-grained homogeneous material, as in conventional spray forming.

As described by Hohmann [17], the CIG system is a water-cooled copper funnel with induction heating to maintain superheat and avoid freezing of the liquid metal as it flows through the funnel. It was first applied to powder production using a plasma melting system for the production of ceramic-free titanium powder [18]. The CIG system is made from copper to avoid introduction of ceramic inclusions that would otherwise be introduced to the melt from conventional ceramic transfer nozzles such as those used to feed powder atomizers.

\section{The CMSF Process}

The combination of ESR, CIG, and spray forming systems results in a new process, termed Clean Metal Spray Forming or CMSF, that has been described several earlier papers by the authors $[19,20,21,22,23]$. Several benefits can be expected from the process:

- The liquid slag dissolves ceramic inclusions that may be present in the VIM electrode, so that outgoing material is cleaner than incoming material.

- Re-contamination of the metal that may otherwise originate from a ceramic transfer tube is avoided through the use of the copper CIG system.

- The process is a "melt-as-needed" process in which large amounts of metal can be processed while only a small amount of metal is liquid at any one time. Chemistry problems generally associated with large melts are reduced. Energy loss to containers is also reduced.

- The economy of the process when compared to powder metal processing is apparent. The number of processing steps between atomization and the final preform are significantly reduced. Spray forming yield is typically higher than $\mathrm{P} / \mathrm{M}$ sieve yield as well.

A pilot plant has been constructed to demonstrate the CMSF concept. The plant was constructed to verify the premise that material generated is satisfactory for commercial purposes and to substantiate the economical viability of the process. This combination of requirements leads to the further requirement that the pilot plant operate at production processing rates using production electrode and preform diameters. Production sized power supplies are required. The primary systems of the resulting plant are shown schematically in Figure 2. The pilot plant is operational and preforms up to $580 \mathrm{lb}$. have been manufactured for evaluation for applicability to rotating components in aircraft engines.

\section{Alloy 718 Evaluation}

The CMSF process has been evaluated for production of Alloy 718. The feed stock was a conditioned $355 \mathrm{~mm}(14 ")$ dia., $1133 \mathrm{~kg}(2500 \mathrm{lb}$.) vacuum induction melted electrode. The electrode was processed in the CMSF equipment using a $70 \% \mathrm{CaF} / 15 \% \mathrm{CaO} / 15 \% \mathrm{Al}_{2} \mathrm{O}_{3}$ slag chemistry and nitrogen was used as the atomizing gas. The processing rate was nominally $14 \mathrm{Kg}(30 \mathrm{lbs})$ per minute, however the metal pour rate was allowed to decrease from start to finish - late in the run the spray forming conditions were too cold. This impacted the quality of the preform, as described later. The resulting preform, measuring $241 \mathrm{~mm}\left(9.5^{\prime \prime} \mathrm{dia}\right) \times 330 \mathrm{~mm}$ (13") dia $\times 123 \mathrm{Kg}(272 \mathrm{lbs})$, was used for this evaluation.

A starter plate separates the ESR pool from the CIG nozzle during the starting phase of operation. As part of the starting process, this starter plate is melted and caused to mix with the refined ESR melt pool. Because the metal of the starter plate does not pass through the slag, it must be made from previously refined material. The composition of the starter plate, chosen for 
cost-effectiveness in this evaluation only, was Alloy 706. A cross section of the starter plate and ESR/CIG region after a melt is shown in Figure 3. The heat-affected zone in the starter plate is clearly visible in the photograph. Also visible is the refined superalloy, which fills the crucible and flows through the starter plate to fill the CIG. As is the case with all similar crosssectional views, some remnants of unmelted slag are visible at the periphery of the ingot directly above the starter plate. This is seen in conventional ESR billets as well. One of the goals of the ongoing study is to verify that this slag cannot be trapped in the out-flowing metal stream.

\section{As-Sprayed Preform Characterization}

Unsound material was removed from the ends of the preform and a longitudinal cross sectional slice was cut from the center of the preform to be used to characterize the as-sprayed material properties. Testing included surface porosity measurements, density, macrostucture, microstructure and chemical composition.

The depth of surface porosity was measured on the etched macro slice at various locations and later confirmed by optical microscopy. The grain structure and second phase precipitates were characterized using both optical and electron microscopy at top and bottom locations as a function of radial position.



Figure 2 CMSF Pilot Plant. This plant is in operation at GE Corporate R\&D. 
Table I compares the chemical compositions of the Alloy 706 starter plate, the Alloy 718 electrode, and the resulting CMSF preform at various locations along with the AMS 5662 specification. Nitrogen atomization resulted in a significant increase in the nitrogen level relative to the VIM feed stock. However, as discussed in [24], the extremely small (submicron) nitride particles do not appear to be detrimental to mechanical properties. The composition of the preform is similar to, but not identical to, that of the original vacuum induction melted electrode. The difference in chemical composition between the preform and the original electrode can be attributed to dilution of the molten metal pool by the Alloy 706 starter plate. As expected, radial compositional uniformity at any lengthwise preform location was acceptable. Table 1 shows that the starter plate composition (Alloy 706) contains more iron than Alloy 718 and the iron content of the preform is elevated over that of the starting electrode. Except for $\mathrm{Nb}$ and $\mathrm{Mo}$, the chemical composition of the preform remained within the AMS specification for Alloy 718. Production of spray formed Alloy 718 will require a starter plate of matching chemistry.

Considerable porosity was found at the edges of the preform and extend toward the center by as much as $25 \mathrm{~mm}\left(1.0^{\prime \prime}\right)$. The porous layer at the OD was made up of two distinct regions: an outer region of "feathery" deposits with large interconnected pores, and a second region with many prior particle boundaries and significant isolated porosity. The first "feathery" layer has been attributed to a wide-diameter spray cone, and subsequent testing has verified that a tighter spray significantly reduces the region. The second region has been attributed to a spray temperature that was too cold. Since the economy of the process is driven by large diameter and low OD porosity, two conflicting criteria, significant experimental effort is necessary to reduce the affected region.

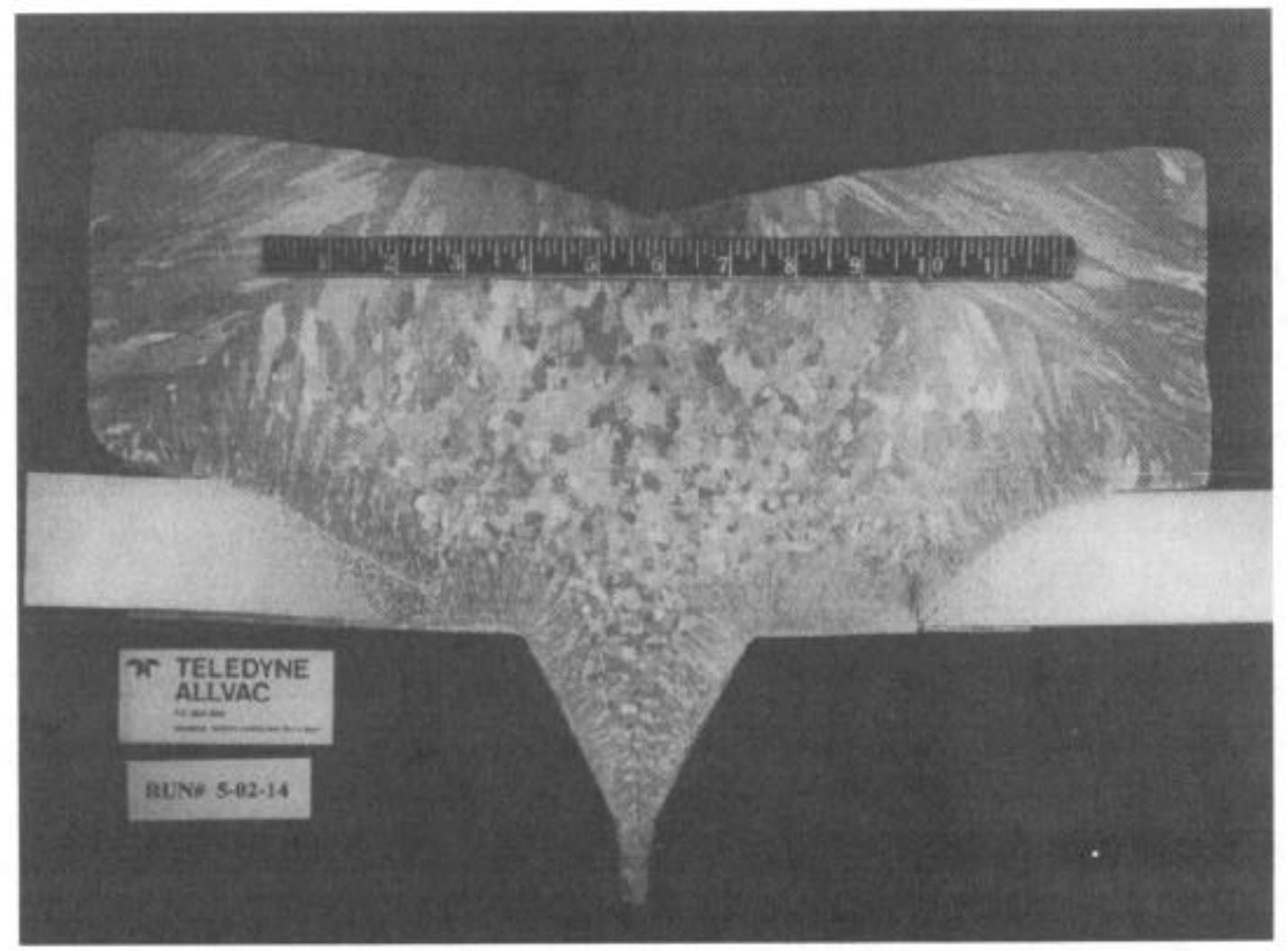

Figure 3 ESR/CIG Cross Section 
Table 1 Spray Formed Alloy 718 Chemical Analysis (wt.\%)

\begin{tabular}{|c|c|c|c|c|c|c|c|c|c|c|c|}
\hline \multirow[t]{2}{*}{ Element } & \multirow[t]{2}{*}{$\begin{array}{l}\text { Alloy } 718 \\
\text { Electrode }\end{array}$} & \multirow{2}{*}{$\begin{array}{c}\text { Alloy } \\
706 \\
\text { Starter } \\
\text { Plate }^{(1)}\end{array}$} & \multicolumn{7}{|c|}{ Position From Bottom of Preform } & \multicolumn{2}{|c|}{$\begin{array}{c}\text { AMS 5662 } \\
\text { Specification }\end{array}$} \\
\hline & & & $0^{\prime \prime}$ & $1.5^{\prime \prime}$ & $3 "$ & $4.5^{\prime \prime}$ & $6^{\prime \prime}$ & $7.5^{\prime \prime}$ & $9^{\prime \prime}$ & Min. & Max. \\
\hline $\mathrm{C}$ & 0.021 & 0.015 & 0.025 & - & - & - & - & - & 0.024 & - & 0.08 \\
\hline $\mathrm{S}$ & 0.0005 & 0.0004 & 0.0004 & - & - & - & - & - & 0.0005 & - & 0.015 \\
\hline $\mathrm{O}$ & $<0.0005$ & 0.0013 & 0.0010 & - & - & - & - & - & 0.0008 & - & - \\
\hline $\mathrm{N}$ & 0.0080 & 0.0028 & 0.0253 & - & - & - & - & - & 0.0279 & - & 一 \\
\hline Mo & 2.91 & 0.10 & 2.33 & 2.34 & 2.38 & 2.45 & 2.53 & 2.59 & 2.64 & 2.80 & 3.30 \\
\hline $\mathrm{Cr}$ & 17.93 & 16.08 & 17.58 & 17.71 & 17.82 & 17.80 & 17.72 & 17.77 & 17.82 & 17.00 & 21.00 \\
\hline $\mathrm{Co}$ & 0.25 & 0.03 & 0.32 & 0.31 & 0.31 & 0.30 & 0.29 & 0.28 & 0.28 & - & 1.00 \\
\hline $\mathrm{Fe}$ & 17.36 & 36.85 & 21.30 & 21.21 & 21.00 & 20.58 & 20.02 & 19.54 & 19.17 & $\mathrm{Bal}$ & $\mathrm{Bal}$ \\
\hline $\mathrm{Cu}$ & 0.05 & 0.01 & 0.05 & 0.05 & 0.05 & 0.06 & 0.06 & 0.06 & 0.06 & - & 0.30 \\
\hline $\mathrm{P}$ & 0.003 & 0.006 & 0.003 & 0.003 & 0.003 & 0.003 & 0.003 & 0.003 & 0.003 & - & 0.015 \\
\hline $\mathrm{Nb}$ & 5.44 & 3.00 & 4.81 & 4.55 & 4.49 & 4.66 & 5.02 & 5.09 & 5.15 & 4.75 & 5.50 \\
\hline $\mathrm{Mn}$ & 0.10 & 0.08 & 0.09 & 0.09 & 0.09 & 0.09 & 0.09 & 0.09 & 0.09 & - & 0.35 \\
\hline $\mathrm{Ti}$ & 1.00 & 1.64 & 0.98 & 0.95 & 0.94 & 0.95 & 0.97 & 0.96 & 0.95 & 0.65 & 1.18 \\
\hline $\mathrm{Al}$ & 0.59 & 0.22 & 0.55 & 0.54 & 0.54 & 0.54 & 0.52 & 0.53 & 0.53 & 0.20 & 0.80 \\
\hline $\mathrm{Si}$ & 0.05 & 0.05 & 0.07 & 0.07 & 0.07 & 0.06 & 0.06 & 0.06 & 0.06 & - & 0.35 \\
\hline $\mathrm{Ni}$ & 53.80 & 41.91 & 51.49 & 51.60 & 51.89 & 52.06 & 52.27 & 52.51 & 52.71 & 50.00 & 55.00 \\
\hline
\end{tabular}

1) Alloy 706 billet top \& bottom average.

2) Chemistry samples taken from the preform centerline following a 0.5 " top crop and a $2.5^{\prime \prime}$ bottom crop.

Table 2 gives the densities at different locations on the as-sprayed preform. With the exception of the densities at the top of the preform, density was in excess of $99 \%$ of the theoretical density. As mentioned above, the metal pour rate was allowed to drop as the run progressed, resulting in an increasingly cold spray. High porosity results near the end of the run.

\section{As-Sprayed Hot Workability}

Rapid strain rate elevated temperature tensile properties were obtained to evaluate the hot ductility characteristics of the material between $871^{\circ} \mathrm{C}-1093^{\circ} \mathrm{C}\left(1600^{\circ} \mathrm{F}-2000^{\circ} \mathrm{F}\right)$. Both the strength and ductility exhibit significant variability at $982^{\circ} \mathrm{C}\left(1800^{\circ} \mathrm{F}\right)$ and below (Table 3$)$ but appear to be adequate for hot workability.

\section{Mechanical Properties}

Mechanical properties were measured on specimens taken from forged pancake samples. These were prepared from coupons measuring $51 \mathrm{~mm} \times 51 \mathrm{~mm} \times 70 \mathrm{~mm}\left(2^{\prime \prime} \times 2^{\prime \prime} \times 2.75^{\prime \prime}\right)$ which were upset forged on a 1000 ton open die press forge without reheating to $16 \mathrm{~mm}\left(0.625^{\prime \prime}\right)$ in height at $982^{\circ} \mathrm{C}\left(1800^{\circ} \mathrm{F}\right)$. Die chilling during forging was minimized by coating the coupons with ATP 790, a high temperature lubricant, and sandwiching them between metallic insulating plates. The forging dies were heated to approximately $538^{\circ} \mathrm{C}\left(1000^{\circ} \mathrm{F}\right)$ using gas torches.

Following hot forging and prior to testing, samples were solution annealed and double aged in accordance with AMS 5662 as follows:

Solution anneal: $\quad 954^{\circ} \mathrm{C}\left(1750^{\circ} \mathrm{F}\right) / 1 \mathrm{hr} / \mathrm{AC}$

1st Aging cycle: $\quad 718^{\circ} \mathrm{C}\left(1325^{\circ} \mathrm{F}\right) / 8 \mathrm{hr} / \mathrm{FC} @ 38^{\circ} \mathrm{C}\left(100^{\circ} \mathrm{F}\right) / \mathrm{hr}$ to $621^{\circ} \mathrm{C}\left(1150^{\circ} \mathrm{F}\right)$

2nd Aging cycle: $\quad 621^{\circ} \mathrm{C}\left(1150^{\circ} \mathrm{F}\right) / 8 \mathrm{hr} / \mathrm{AC}$ 
Table 2 As-Sprayed 718 Density Measurements

\begin{tabular}{|l|c|c|}
\hline \multicolumn{1}{|c|}{$\begin{array}{c}\text { Sample } \\
\text { Location }\end{array}$} & $\begin{array}{c}\text { Relative } \\
\text { Density } \\
\text { wrt 718 } \\
\text { Standard }\end{array}$ & $\begin{array}{c}\text { Density } \\
( \pm .0009 \\
\mathrm{g} / \mathbf{c c})\end{array}$ \\
\hline 718 Standard & 100.002 & 8.2341 \\
\hline $\begin{array}{l}\text { Bottom } \\
\text { Center }\end{array}$ & 99.596 & 8.2007 \\
\hline $\begin{array}{l}\text { Bottom Mid- } \\
\text { Radius }\end{array}$ & 99.596 & 8.2007 \\
\hline $\begin{array}{l}\text { Butluur } \\
\text { Surface }\end{array}$ & 99.478 & 8.1909 \\
\hline Mid Center & 99.109 & 8.2018 \\
\hline $\begin{array}{l}\text { Mid Mid- } \\
\text { Radius }\end{array}$ & 99.679 & 8.2075 \\
\hline Mid Surface & 99.906 & 7.8958 \\
\hline Top Center & 94.587 & 7.7883 \\
\hline $\begin{array}{l}\text { Top Mid- } \\
\text { Radius }\end{array}$ & 95.097 & 7.7809 \\
\hline Top Surface & 94.291 & 7.7639 \\
\hline
\end{tabular}

Table 3 As-Sprayed Alloy 718 Rapid Strain Rate Hot Tensile Test

\begin{tabular}{|c|c|c|c|}
\hline $\begin{array}{c}\text { Temperature } \\
{ }^{\circ} \mathbf{C}\left({ }^{\circ} \mathbf{F}\right)\end{array}$ & $\begin{array}{c}\text { UTS MPa } \\
\text { (ksi) }\end{array}$ & $\begin{array}{c}\% \\
\text { El }\end{array}$ & $\begin{array}{c}\% \\
\text { RA }\end{array}$ \\
\hline \multirow{2}{*}{$871(1600)$} & $392.4(56.9)$ & 5.8 & 3.1 \\
\cline { 2 - 4 } & $461.4(66.9)$ & 42.2 & 48.4 \\
\hline \hline \multirow{2}{*}{$927(1700)$} & $305.5(44.3)$ & 69.3 & 58.8 \\
\cline { 2 - 4 } & $271.7(39.4)$ & 10.8 & 16.0 \\
\hline \hline \multirow{2}{*}{$982(1800)$} & $195.8(28.4)$ & 22.7 & 17.0 \\
\cline { 2 - 4 } & $238.6(34.6)$ & 38.2 & 42.8 \\
\hline \hline \multirow{2}{*}{$1038(1900)$} & $155.8(22.6)$ & 86.4 & 78.4 \\
\cline { 2 - 5 } & $153.1(22.2)$ & 95.3 & 81.7 \\
\hline \hline \multirow{2}{*}{$1093(2000)$} & $113.1(16.4)$ & 100.1 & 82.7 \\
\cline { 2 - 5 } & $111.7(16.2)$ & 72.9 & 74.6 \\
\hline
\end{tabular}

1). Test bars were cut from the center location and oriented parallel to the preform longitudinal axis.

2) All tests performed on the as-sprayed material.

As shown in Table 4, room temperature and elevated temperature tensile properties and hardness were all acceptable relative to the specification requirements and were comparable to property levels reported previously for spray formed 718 [25]. In the hot forged plus solution annealed condition, the average grain size was rated as ASTM 9-10 with isolated grains as large as ASTM 6.

\section{Oxide Cleanliness}

As discussed in the introduction, oxide cleanliness is the primary incentive for developing the new process. For this study, the electron beam button test [26] was used to evaluate the cleanliness. Five $38 \mathrm{~mm} \times 38 \mathrm{~mm} \times 162 \mathrm{~mm}\left(1.5^{\prime \prime} \times 1.5^{\prime \prime} \times 6.375^{\prime \prime}\right)$ blanks from the top half of the as-sprayed preform were machined into EB electrodes. Cleanliness was evaluated by measuring various parameters of the oxide raft on the surface of the FB melted button. Using secondary and back scattered electron imaging techniques, oxide particles greater than or equal to $0.5 \mathrm{mil}^{2}$ were detected, counted and measured for surface area. The test utilized a semiautomated AMRAY 1830T4 scanning electron microscope (SEM) equipped with an energy dispersive x-ray (EDX) system and a thin-window, solid state light element detector. Surface area measurements were performed using an integrated KEVEX image analysis system. For each individual button, the total oxide area was calculated and divided by the button weight, resulting in the specific oxide area or oxide cleanliness, which is reported in $\mathrm{mm}^{2} / \mathrm{kg}$. The qualitative x-ray composition of the five largest oxides in cach button was also determined.

Table 5 compares the oxide cleanliness of as-sprayed 718 with the cleanliness of the initial VIM electrode and rapid melt rate ESR materials. No oxides were visible in any of the buttons 
Table 4 Spray Formed 718 Tensile Properties

\begin{tabular}{|c|c|c|c|c|c|}
\hline Test & $\begin{array}{l}\text { UTS } \\
\text { MPA } \\
(\mathbf{k s i})\end{array}$ & $\begin{array}{c}0.2 \% \text { YS } \\
\text { MPA } \\
\text { (ksi) }\end{array}$ & $\begin{array}{l}(\%) \\
\text { EL }\end{array}$ & $\begin{array}{l}(\%) \\
\text { RA }\end{array}$ & $\begin{array}{c}\text { Hardness } \\
\text { (HRC) }\end{array}$ \\
\hline \multirow[t]{2}{*}{ RTT } & $\begin{array}{l}1411.0 \\
(204.6)\end{array}$ & $\begin{array}{c}1126.2 \\
(163.3)\end{array}$ & 23.3 & 38.2 & 42.8 \\
\hline & $\begin{array}{l}1418.0 \\
(205.6)\end{array}$ & $\begin{array}{c}1138.0 \\
(165.0)\end{array}$ & 23.6 & 39.2 & 43.4 \\
\hline \multirow{2}{*}{$\begin{array}{c}649^{\circ} \mathrm{C} \\
\left(1200^{\circ} \mathrm{F}\right) \\
\text { ETT }\end{array}$} & $\begin{array}{l}1104.1 \\
(160.1)\end{array}$ & $\begin{array}{c}917.9 \\
(133.1)\end{array}$ & 25.7 & 36.6 & 43.9 \\
\hline & $\begin{array}{l}1100.0 \\
(159.5)\end{array}$ & $\begin{array}{c}922.1 \\
(133.7) \\
\end{array}$ & 25.7 & 38.1 & 42.4 \\
\hline $\begin{array}{c}\text { AMS 5662- } \\
\text { RTT } \\
\text { (Minimums) }\end{array}$ & $\begin{array}{c}1276.0 \\
(185)\end{array}$ & $\begin{array}{c}1034.0 \\
(150)\end{array}$ & 12 & 15 & 35 \\
\hline $\begin{array}{c}\text { AMS } 5662 \\
649^{\circ} \mathrm{C} \\
\left(1200^{\circ} \mathrm{F}\right) \\
\text { ETT } \\
\text { (Minimums) }\end{array}$ & $\begin{array}{l}1000.0 \\
(145)\end{array}$ & $\begin{array}{l}862.0 \\
(125)\end{array}$ & 12 & 15 & $\mathrm{~N} / \mathrm{A}$ \\
\hline
\end{tabular}

Heat Treatment

Solution Anneal: $954^{\circ} \mathrm{C}\left(1750^{\circ} \mathrm{F}\right) / 1 \mathrm{hr} / \mathrm{AC}$

1st Aging Cycle:

$718^{\circ} \mathrm{C}\left(1325^{\circ} \mathrm{F}\right) / 8 \mathrm{hr} / \mathrm{FC} @ 38^{\circ} \mathrm{C}\left(100^{\circ} \mathrm{F}\right) / \mathrm{hr}$ to $621^{\circ} \mathrm{C}$

$\left(1150^{\circ} \mathrm{F}\right)$

2nd Aging Cycle: $\quad 621^{\circ} \mathrm{C}\left(1150^{\circ} \mathrm{F}\right) / 8 \mathrm{hr} / \mathrm{AC}$

laken from CMSF preforms. While these dala are preliminary, they do suggest a marked improvement in oxide cleanliness as a result of clean metal spray forming. It should be noted that this preform was sprayed using nitrogen gas, and a nitride raft formed at the top of all buttons. Metallography was performed on cross sections taken from some of the buttons to determine if the observed nitride raft in any way obscured oxides; no hidden oxides were found. EB buttons taken from conventionally melted, nitrogen-atomized preforms show large numbers of oxides despite the presence of the nitride raft.

\section{Conclusions}

Direct processing of ESR material by bottom pouring from an ESR furnace has been demonstrated as a feasible process through the construction of a pilot plant. The pilot plant was designed to operate at production rates and power levels, using production-sized VIM electrodes. A cold-walled-induction guide was constructed to transfer metal from the ESR furnace melt pool into the spray forming chamber as a stream of liquid metal. The resulting process is termed Clean Metal Spray Forming.

An evaluation has been performed on nitrogen-atomized Alloy 718 produced by CMSF. The as-sprayed preform was characterized by a non-uniform chemical composition and the presence of a surface layer of porosity that extended to depths of 1" in the worst case. Except for Mo and $\mathrm{Nb}$, the chemistry of the preform was acceptable per AMS 5662. The microstructure was 
Table 5 CMSF 718 Electron Beam Button Cleanliness Data

\begin{tabular}{|c|c|c|c|c|c|}
\hline Position & $\begin{array}{l}\text { Total No. } \\
\text { of Oxides }\end{array}$ & $\begin{array}{l}\text { Total Oxide } \\
\text { Area } \\
\text { (sq. mil) }\end{array}$ & $\begin{array}{l}\text { Button } \\
\text { Weight } \\
\text { (g) }\end{array}$ & $\begin{array}{c}\text { Specific Oxide } \\
\text { Area (sq. } \\
\mathrm{mm} / \mathrm{kg} \text { ) }\end{array}$ & $\begin{array}{c}\text { Major EDX } \\
\text { Peaks }\end{array}$ \\
\hline \multirow{3}{*}{$\begin{array}{l}\text { VIM- } \\
\text { Bottom }\end{array}$} & - & $414.9^{(*)}$ & 610.2 & 0.439 & $\Lambda \mathrm{l} / \mathrm{O}$ \\
\hline & - & $140.0^{(*)}$ & 611.1 & 0.148 & $\mathrm{Al} / \mathrm{Mg} / \mathrm{O}$ \\
\hline & - & $278.3^{(+)}$ & 581.1 & 0.309 & $\mathrm{Al} / \mathrm{Mg} / \mathrm{O}$ \\
\hline \multirow{6}{*}{$\begin{array}{l}\text { High Melt- } \\
\text { Rate ESR }\end{array}$} & 0 & 0 & 537.3 & 0.000 & - \\
\hline & 0 & 0 & 522.3 & 0.000 & - \\
\hline & 23 & 8.6 & 499.6 & 0.049 & Not Measured \\
\hline & 2 & 0.7 & 561.3 & 0.001 & Not Measured \\
\hline & 0 & 0 & 527.3 & 0.000 & - \\
\hline & 0 & 0 & 553.0 & 0.000 & - \\
\hline \multirow{5}{*}{$\begin{array}{c}\text { CMSF- } \\
\text { Top }\end{array}$} & 0 & $\overline{0}$ & 649.5 & 0 & - \\
\hline & 0 & 0 & 683.6 & 0 & - \\
\hline & 0 & 0 & 676.7 & 0 & - \\
\hline & 0 & 0 & 660.5 & 0 & - \\
\hline & 0 & 0 & 654.3 & 0 & - \\
\hline
\end{tabular}

*Oxide agglomerate

characterized by an equiaxed ASTM 6 grain size with isolated porosity. Following a limited amount of hot deformation, the material exhibited solution annealed plus aged tensile properties, hardness, and solution annealed grain size that were acceptable relative to the requirements outlined in AMS 5662. Preliminary EB button test data suggested marked improvements in oxide cleanliness were possible using the CMSF process.

\section{Acknowledgments}

The authors acknowledge the many helpful discussions with the following contributors during this effort: T.B. Cox, P.J. Frischmann, H.R. Hart, and T.F. Sawyer of GE-CRD; E.S. Huron, R.G. Menzies, D.P. Mourer, and M.J. Weimer of GE Aircraft Engines; C.B. Adasczik of Teledyne Allvac; M. Hohmann, F.W. Hugo, and F.G. Müller of ALD Vacuum Technologies; and R.G. Brooks, J.S. Coombs, J. Forrest and A.G. Leatham of Osprey Metals, Ltd.

\section{References}

1 D.R. Chang, D.D. Kreuger, and R.A. Sprague: "Superalloy Powder Processing, Properties and Turbine Applications," Superalloys 1984, Proceedings of Fifth International Symposium on Superalloys, TMS-AIME, Warrendale, PA, 1984, pp. 245-273.

2 H.C. Fiedler, T.F. Sawyer and R.W. Kopp: "Spray Forming - An Evaluation Using IN718," Proceeding of the 1986 Vacuum Metallurgy Conference on Specialty Metals Melting and Processing, pp. 157-165, 1986.

3 G. Hoyle, Electroslag Process, Principles and Practice, Applied Science Publishers Ltd., London, 1983.

4 R.W. Evans, A.G. Leatham, R.G. Brooks, "The Osprey Preform Process," Powder Metallurgy, 1985, vol. 29, pp. 61-68.

5 A.G. Leatham, A. Lawlcy, "The Osprey Process: Principles and Applications," International Journal of Powder Metallurgy, Vol. 29, No. 4, pp. 321-329, 1993.

6 A.G. Leatham, "A Progressive Review of the Osprey Process since ICSF1," Proceedings of the Second International Conference on Spray Forming, Swansea, Sept. 13-15, 1993. 
7 R.H. Bricknell, "The Structure and Properties of a Nickel-Based Superalloy Produced by Osprey AtomizationDeposition," Met. Trans., 1986, vol. 17A, pp. 583-591.

8 H.C. Fiedler, T.F. Sawyer and R.W. Kopp: "Spray Forming - An Evaluation Using IN718," Proceeding of the 1986 Vacuum Metallurgy Conference on Specialty Metals Melting and Processing, pp. 157-165, 1986.

9 H.C. Fiedler, T.F. Sawyer, R.W. Kopp and A.G. Leatham: "The Spray Forming of Superalloys," Journal of Metals, 1987, vol. 39, no. 8, pp. 28-33.

10 K-M Chang and H.C. Fiedler: "Spray-Formed High-Strength Superalloys," Superalloys 1988, Proceedings of the Sixth International Symposium on Superalloys, Edited by S. Reichman, et al, TMS-AIME, pp. 485-493, 1988.

11 R.L. Kennedy, R.M. Davis and F.P. Vaccaro: "An Evaluation of Spray Formed Alloy 718," Superalloy 718 Metallurgy and Applications, Edited by E.A. Loria, TMS-AIME, pp. 97-108, 1989.

12 M.G. Benz, T.F. Sawyer, F.W. Clark and P.L. Dupree: "Properties of Superalloys Spray Formed at Process Flow Rates of Less Than $20 \mathrm{~cm} 3 / \mathrm{s}$," Proceedings of the First International Conference on Spray Forming, Swansea, Wales, UK 17th - 19th September, 1990.

13 M.G. Benz, T.F. Sawyer, F.W. Clark and P.L. Dupree: "Nitrogen in Spray Formed Superalloys," Proceedings of the Second International Conference on Spray Forming, Swansea, Wales, UK 13th - 15th September, 1993.

14 A.L. Moran and W.A. Palko.: "Spray Forming Alloy 625 Marine Piping," Journal of Metals, 1988, vol. 40, no. 12 , pp. 12-15.

15 E.S. Huron, "Properties of Sprayformed Superalloy Rings," Proceedings of the Second International Conference on Spray Forming, Swansea, Sept. 13-15, 1993.

16 P.D. Prichard and R.P. Delal: "Spraycast-X Superalloy for Aerospace Applications," Superalloys 1992, Proceedings of the Seventh International Symposium on Superalloys, Edited by S.D. Antolovich, et al,TMSAIME, Warrendale, PA, pp. 205-214, 1992.

17 M. Hohman, M. Ertl, A. Choudhury, and N. Ludwig, "Experience with Ceramic-Free Powder Production Methods," 1991 - P/M in Aerospace and Defense Technologies, Metal Powder Industries Federation, Princeton, NJ, pp. 261-272.

18 R. Gerling, F.R. Schimansky, and R. Wagner, "Progress in Atomizing High Melting Intermetallic Titanium Based Alloys by Means of a Novel Plasma Melting Induction Guiding Gas Atomization Facility," Vol. 1, Powder Metallurgy World Congress, PM'94, pp. 387-390.

19 W.T. Carter, Jr., M.G. Benz, F.G. Müller, R.M. Forbes Jones, A.G. Leatham, "Electroslag Remelting As A Liquid Metal Source For Spray Forming," 1995 International Conference on Powder Metallurgy and Particulate Processing, Seattle, May 14-17, 1995.

20 W.T. Carter, Jr., M.G. Benz, F.G. Müller, R.M. Forbes Jones, "Electroslag Refining As A Liquid Metal Source For Spray Forming," European Conference on Advanced PM Materials, Birmingham, Oct. 23-25, 1995.

21 M.G. Benz, W.T. Carter, Jr., R.J. Zabala, B.A. Knudsen, P.L. Dupree, and F.G. Muller, "Electroslag Refining as a Liquid Metal Source for Powder Atomization, Spray Deposition, Investment Casting, Melt-Spinning, Strip Casting, and Slab Casting," Spring 1996 TMS Annual Meeting, Anaheim. Feb. 4-8, 1996.

22 W.T. Carter, J.M. Koca, M.G. Benz, D.P. Mourer, R.M. Forbes Jones, R.M. Davis, R.L. Kennedy, "A Clean Metal Spray Forming System for Superalloys," Third International Conference on Spray Forming, Cardiff, 1996.

23 R.M. Forbes Jones, R.M. Davis, R.L. Kennedy, W.T. Carter, Jr., M.G. Benz, "Characteristics of Clean Metal Spray Formed Material," Third International Conference on Spray Forming, Cardiff, Sept. 9-11, 1996.

24 M.G. Benz, R.J. Zabala, B.A. Knudsen, W.T. Carter, Jr., T.F. Sawyer, "Spray Formed Alloy 718, "Superalloys 718, 625, 706 and Derivatives, Pittsburgh, PA, June 27-29, 1994.

25 R.L. Kennedy, R.M. Davis, F.P. Vaccaro, “An Evaluation of Spray Formed Alloy 718," Superalloy 718 Metallurgy and Applications, E.A. Loria, Ed., TMS-AIME, 1989, pp. 97-108.

26 J.M. Moyer, L.A. Jackman, C.B. Adasczik, R.M. Davis, and R.M. Forbes Jones: "Advances in Triple Melting Superallnys 718, 706 and 625," Superalloys 718, 625, 706 and Derivatives, Pittsburgh, PA, June 27-29, 1994 